Mitteilungen der Österreichischen Geographischen Gesellschaft, 162. Jg., S. 43-63

(Annals of the Austrian Geographical Society, Vol. 162, pp. 43-63)

Wien (Vienna) 2020, https://doi.org/10.1553/moegg162s43

\title{
Global City Mirage: Depoliticising Urban TRANSFORMATION IN BELGRADE AND TIRANA ${ }^{1)}$
}

\author{
Hend ALY, Cairo [al-Qāhirah]* \\ Initial submission / erste Einreichung: 05/2020; revised submission / revidierte Fassung: 09/2020; \\ final acceptance / endgültige Annahme: 12/2020 \\ with 1 table in the text
}

\section{CONTENTS}

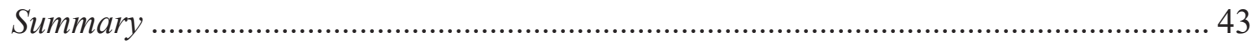

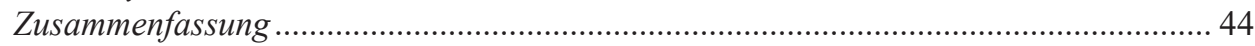

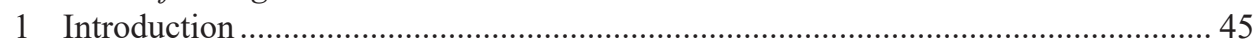

2 Conceptual debates on periperalisation and depolitication .................................... 46

3 Same same but different: identifying proximity between paradigms of developing megaprojects in the core and the periphery.......................................................... 50

4 Entangled and intricately connected processes of depoliticisation and

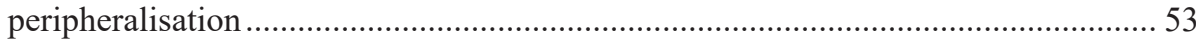

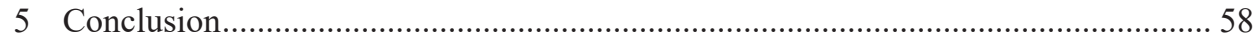

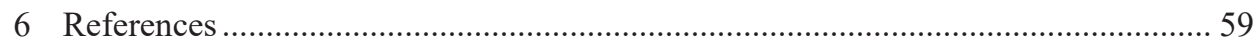

\section{Summary}

The article discusses global city aspirations as a mirage which Belgrade and Tirana are continuously trying to attain. Catching this mirage is the guiding rationale of urban transformations in the two cities. Importantly, I argue that peripherality and the aspirations to be more central legitimise certain urban governance strategies, specifically depoliticising urban transformation. The article demonstrates that eventually depoliticisation strategies backfire and, instead, lead to further peripheralisation. Hence, the study explores the relation between peripheralisation and depoliticising urban transformation in Belgrade and Tirana as cities which employ their urban transformation to catch up with global cities. It empirically explores this relation through analysing governance discourses and practices of two megaprojects, the Belgrade Waterfront (BWF) and the

\footnotetext{
1) I would like to thank Chris AzIz and Moritz Minatsch for their continuous support, language edits and comments.

* Hend Aly, M.A., Urban Governance Specialist, UN Habitat Egypt Country Office, Housing and Building Research Center, 87 Tahrir Street, Doki, Giza, Egypt. - Email: hend.aly@un.org.
} 
New National Theatre in Tirana. The analysis addresses three main questions, the first one is on the nature of depoliticisation and how it is practiced, while the second and the third questions tackle the entangled relation between depoliticisation and peripheralisation.

Conceptually, the article draws on the scholarly debates on the concepts of peripheralisation and depoliticisation. The research is mainly based on semi-structured interviews with state officials, experts and activists, observations, project related official and branding documents and official statements. Fieldtrips were organised to Belgrade and Tirana in winter 2018-2019 and summer 2019.

Keywords: Governance, urban development, urban transformation, peripheralisation, depoliticisation, global city, megaprojects, Tirana, Belgrade

\section{Zusammenfassung}

\section{Weltstadt als Illusion: Die ENTPOLITISIERUNG DER Stadtentwicklung VON Belgrad und Tirana}

In diesem Artikel werden die Weltstadt-Bestrebungen als eine Illusion, die Belgrad und Tirana ständig zu erreichen versuchen, analysiert. Dieses Traumbild einzufangen, ist das Leitmotiv der städtischen Transformationen in den beiden Städten. Ich argumentiere, dass die Peripheralität und das Streben nach mehr Zentralität bestimmte Governance-Strategien legitimieren, insbesondere die Entpolitisierung der Stadtentwicklung. Der Artikel zeigt auf, dass Entpolitisierungsstrategien letztlich kontraproduktiv sind und stattdessen zu einer weiteren Peripheralisierung führen. Daher untersuche ich in der vorliegenden Studie die Beziehung zwischen Peripheralisierung und Entpolitisierung der Stadtentwicklung in Belgrad und Tirana - Städte, die ihre städtische Transformation zu nutzen versuchen, um zu Weltstädten aufzuschließen. Empirisch wird dieser Zusammenhang durch die Analyse der Governance-Diskurse und-Praktiken zweier Megaprojekte, der „Belgrade Waterfront“ (BWF) und des Neuen Nationaltheaters in Tirana, beleuchtet. Die Analyse befasst sich mit drei Hauptfragen: Die erste betrifft das Wesen der Entpolitisierung und die Art und Weise, wie sie praktiziert wird, während sich die zweite und die dritte Frage mit der verschränkten Beziehung zwischen Entpolitisierung und Peripheralisierung befassen.

Konzeptionell stützt sich der Artikel auf die wissenschaftichen Debatten über die Konzepte der Peripheralisierung und der Entpolitisierung. Die empirische Analyse basiert hauptsächlich auf Leitfadeninterviews mit Staatsbeamten, Experten und Aktivisten, Beobachtungen, projektbezogenen offiziellen und Branding-Dokumenten und offiziellen Stellungnahmen. Die Feldforschung in Belgrad und Tirana erfolgte im Winter 2018-2019 und im Sommer 2019.

Schlagwörter: Governance, Stadtentwicklung, städtische Transformation, Peripheralisierung, Entpolitisierung, Weltstadt, Megaprojekte, Tirana, Belgrad 


\section{Introduction}

"BIG's new theatre will become a crown-jewel of this transformation in the heart of the capital $[\ldots$ and realise the] aspirations of a city going on fifth gear yearning for constant change and place-making." $\left.{ }^{2}\right)$ With these words, Tirana's Mayor presented the New National Theatre designed by a Copenhagen-based top architect, to realise the aspirations of the Albanian capital to be a global city. Such aspirations of the periphery to reposition in the global hierarchy of cities also present the guiding rationale of the practises and discourses governing Belgrade's megaproject, the Belgrade Waterfront (BWF). My study foregrounds such global city mirages as the guiding rationale of urban transformation in Belgrade and Tirana. Importantly, I argue that peripherality and the aspirations to be more central legitimise certain urban governance strategies, specifically depoliticising urban transformation. The article demonstrates that eventually depoliticisation strategies backfire and, instead, lead to further peripheralisation. Hence, my study aims at exploring the relation between peripheralisation and depoliticising urban transformation in Belgrade and Tirana as cities which employ their urban transformation to catch up with global cities.

Tirana's and Belgrade's urban transformations are central components of the Albanian and Serbian post-socialist transitions. Both cities continue to experience massive changes, mirroring their countries' new identity and image and imposing a transformation from their socialist past to the modern capitalist world. Megaprojects are an integral part of the neoliberal urban transformation processes. They are believed to be drivers of economic transformation and signifiers of modernisation.

The article provides analysis of megaprojects in Tirana and Belgrade not just as the physical manifestation of post-socialist transition, but more importantly, as mechanisms of repositioning from the periphery to the core and processes of urban transformation, where governance strategies are situated in space. Importantly, it establishes strong interlinkages between peripheralisation and depoliticisation as the dominant strategy of urban transformation governance. Concretely, I argue that the first legitimises the second, while the second reproduces the first. Hence, peripheralisation is simultaneously a driving force and a product of depoliticising urban transformation.

The article demonstrates that mega urban development projects present a precious opportunity to analyse perceptions of where a city is currently positioned, where it aspires to be through the project and what is likely to be compromised in the process. Thus, such projects demonstrate great potential of studying depoliticisation, peripheralisation and their interlinkages. For that reason, it focuses on the Belgrade Waterfront and the New National Theatre project which are envisioned to enhance their cities competitiveness and realise their worlding aspirations. Both are large-scale mixed-use iconic architecture, located in the city centre, and planned as public-private partnerships (PPPs). The two projects are governed through a set of exclusionary frameworks of technocratic decisions and exceptional regulations. Conceptually, the research engages with academic debates on (1) peripheralisation, geographies of centrality and world city formation, as well as,

\footnotetext{
2) As quoted in Myall 2018 (BIG: Bjarke Ingels Group, a Copenhagen-based internationally well-known top architectural firm).
} 
(2) depoliticisation and the post-political condition. Importantly, it establishes the link between the two.

The analysis is mainly based on two fieldtrips to each of the two cities in the period between 2018-2019. Over 30 interviews were conducted during the research period with pubic figures, politicians and state officials, such as the Belgrade City Architect, an architect in Belgrade's city council, an opposition Member of Parliament of Albania, university professors, journalists and activists in the two cities. Moreover, I have interviewed members of the movements which emerged in contestation to the projects "Don't Let Belgrade Drown" (NDB) and the "Alliance for the Protection of the Theatre". In order to locate narratives within spaces, I visited the sites of the two megaprojects various times. Previously, I had visited the BWF gallery and sales office, located in the Geozavod building and I am on the emailing list of Eagle Hills, the project's developer, to get updates on the development of the project. Moreover, during my two fieldtrips to Tirana, I have regularly attended the daily protests by the Alliance and one of its core member meetings. ${ }^{3)}$

Furthermore, the research includes analysis of official statements by different actors and a broad range of official documents, such as contracts, agreements and master plans as well as projects' branding documents. Moreover, I have closely followed social media pages of the two movements and some state officials.

The study first brings together and presents academic debates on peripheralisation and depoliticisation. This is followed by introducing the BWF and the Theatre project and identifying the parallels between megaprojects in the centre and the periphery. Then, the study provides analysis of discourses and practices of governing the two megaprojects. This is to concretely provide an understanding of how peripherality and the aspirations to acquire a better position legitimise depoliticising urban transformation and how depoliticisation as governance strategy of urban transformation in itself creates further peripheralisation.

\section{Peripheralisation and depoliticisation}

\section{On peripheralisation}

The conception of peripheralisation contributes to constructing an understanding of uneven development within and among cities. It originated from dependency theory and world system theory to explain uneven development among nation-states. According to these theories, forces of the world economy produce core and periphery (WALLERSTEIN 1974; Bodenheimer 1970; CAPoraso 1978; NAMKoOng 1999; GoldFrank 2000). Urbanists and human geography scholars shifted the focus to the city. A myriad of concepts

\footnotetext{
3) Due to the sensitivity of the two megaprojects, and the repressive actions by the state, especially in Serbia, all the interviews conducted with activists are confidential. The activists are only referred to using their initials. For some especially sensitive cases, the initials are made up. Also because of the sensitivity of the issue, a number of state/city officials in Albania in different positions, declined my interview request, saying that they would rather not give any statements on the matter.
} 
evolved on the basis of the core and periphery within the world economy theorisation, including world city, global city, worlding city, global city network, world city archipelago, peripheralisation and polarisation.

Already in the 1960s, HaLl (1966) provided analysis of world cities as centres of business in which their roles and power expand beyond national borders. In his analysis, HALL depicts the shift in the nature of capitalism towards financialisation, which becomes central in the later studies. Importantly, various scholars have provided understanding of world cities as nodes in a network or/and category in a world hierarchy of cities. FRIEDMANN (1986) in his world city hypothesis argues that world cities are organised in a complex spatial hierarchy as sites of concentration of capital, and their global functions are reflected in their production system and employment. While SASSEN $(2002 ; 2005)$ in her global city analysis, argues that cities play a central role in "linking their national economies with global circuits", and as a consequence, form "new geographies of centrality" that bring cities together in cross-border networks. This system is organised around a "hierarchy of centrality", in which a city's position is based on its connectivity within the network.

TAYLOR $(2001 ; 2003 ; 2018)$ has worked extensively on theorising the world city network and corporate globalisation. He argues that cities are nodes and the world economy is a supra-nodal network. How connected a city is within this network is defined by its' share of workflows of important firms. As a result, the world becomes more economically integrated but also more polarised. In his writings, he demonstrates how corporate globalisation is prevailing, arguing that it exists in each "urban locale" around the world. While Taylor asserts that cities are flows and routes rather than spaces and territories, vAN MeEteren and Bassens (2016) insist that looking at cities as places and territories still matters. They have employed a networked conception of the global city and the concept of world city archipelago to provide an understanding of the "capitalised world economy under conditions of financialised globalisation" (2016, p. 78). Their research on the world city archipelago considers the agency of individual cities and states. It highlights the importance of looking at how the socio-spatial practises of world cities "produce an uneven capitalist geography", as well as the relevance of studying the role of the state in constructing world cities within financialised globalisation (see also BASSENS and vAN MeETEREN 2015).

While TAYLOR reaffirms that the global city concept excludes non-global cities, RoY and ONG (2011) introduce the worlding city conception to provide an understanding of the aspirations of cities which were left out by the world city and the global city scholars. The worlding city shifted the focus from studying the achieved position of cities, mainly located in the Global North, to, what they call, the "on-going art of being global" among cities of the Global South. As it is the case for the previously discussed concepts, the hierarchical organisation of cities is a main pillar for the worlding city concept. Importantly, Roy and ONG referred to competition as a constituting component of the world cities hierarchy. As a consequence, ONG (2011) argues that as a result of aspiring to be global cities, the global hierarchy is in a state of permanent formation. In his study on worlding cities in the Middle East, BEIER (2019) also argues that world cities hierarchy is not static as portrayed by world city and global city scholars but rather changing and even negotiable. Roy, ONG, 
and BEIER agreed that such aspirations to be global cities represent the main drivers and guiding rationale of urbanisation.

This connection between urbanisation and world economy is further explored by studies on peripheralisation. PoSCoPP (2015) argues that the importance of employing the concept of peripheralisation in studying Central and Eastern Europe (CEE), is "unveiling relations of power". They also consider the dynamics of world economy as well as employ a spatial approach rather than focusing on the lenses of post-socialist transformation and modernisation.

Peripheralisation has been approached and defined differently by scholars. However, a broad range of academic writings have considered the complexity of peripheralisation and avoided dealing with the periphery as a given geographical location or static position within the world city hierarchy. Peripheralisation has been referred to as a label (ELSENHANS 2015), "practices of conceiving, perceiving [...] what has been labelled peripheral" (FISCHER-TAHIR and NAUMANN 2013, p. 9), multi-dimensional processes of uneven development (PoSCoPP 2015) and rhetoric and representation (PAASI 1995). PAASI (1995, p. 237) argues that despite the importance of economic development in understanding peripherality, the periphery should be understood "more broadly to include the political, ideological and cultural aspects of the production of space". FISCHER-TAHIR and NAUMANN (2013, p. 18) have also emphasised the role of power relations and the symbolic aspects in the production of peripheralisation, they have defined it as:

"A spatially organized inequality of power relations and access to material and symbolic goods that constructs and perpetuates the precedence of the centres over areas that are marginalized."

While Fischer-TAHIR and NAUMANn (2013) and PoSCoPP (2015) emphasise the role of the political decision, PAASI (1995, p. 236) asserts that peripheralisation "is a result of both discursive and non-discursive elements, practices and processes". Hence, they have all agreed that the periphery is a construct.

\section{On depoliticisation}

This section follows up on the lines of thought discussed earlier, that (1) the aspirations of non-global cities' to be global constitute an important factor in shaping their urban development and that (2) periphery is a construct. It does so by exploring the conceptually established links between world economy and peripheralisation with urban development and governance. The analysis then narrows down to the conception of depoliticisation as the explored links will be examined by the article through analysing depoliticisation discourses and practices of urban development in Belgrade and Tirana.

HARVEY (1989) connected the transformation of city governance towards entrepreneurialism, which he identified in the 1980s, to the uneven integration of cities in the world economy. As a consequence, enhancing competitiveness and fostering economic growth became among the city's pressing needs and main responsibilities. Furthermore, HARVEY's (2001) spatial fix and SMITH's (1984) works established the connection between the production of space and financial capitalism tightly. This relation has been explored further by studies analysing urban development projects that are thought to enhance cities com- 
petitiveness and their positionality within the world economy (SWYNGEDOUW et al. 2002; WiLson and Swyngedouw 2014; Vukmirović 2015; Vento 2017; Aly 2019), while a number of urban studies on peripheralisation have established the relations between peripheralisation and urban development (FISCHER-TAHIR and NAUMANN 2013; PoSCoPP 2015; CARTER 2015). More specifically, CARTER explored the relation between urban planning and peripheralisation through arguing that planning contributes to constituting places as central or peripheral.

Although depoliticisation has been identified in studies on mega urban development projects, as discussed in the next section, the link between concepts of peripheralisation, and depoliticisation as governance strategy has not been sufficiently explored. My study sustains and further explores the links between peripheralisation and urban governance and transformation. It does so through contextualising the discourses and practices of depoliticisation in governing Belgrade's and Tirana's urban transformation. Depoliticisation of urban transformation here is not only the product of internal factors but also of regional and global trends. A deeper look into urban transformation governance in Belgrade and Tirana shows how the two cities are attempting to fulfil their aspirations to be global cities through copying the attributes of those in the centre not only based on transforming the built environment, but also through replicating their economic growth models and urban governance strategies.

For that reason, this section discusses the concepts of the post-political condition and depoliticisation and shows the value and limitations of the concepts' application on not fully democratic contexts, as they have originally emerged to analyse democracies of the Global North and the deficiencies of democratic rule. However, depoliticisation also takes place in less democratic contexts, as my study demonstrates. Political systems in the Western Balkans do not qualify to be defined as fully democratic, although, they are not fully authoritarian. For that reason, various concepts have been developed to analyse them, such as semi-authoritarianism, semi-democracy, hybrid system, as well as competitive authoritarianism. In my study, I refer to them as competitive authoritarian systems. According to BIEBER (2018), in such regimes, democracy is being reduced to elections, and politics is being shaped through authoritarian practices. I argue that, in a competitive authoritarian context, authoritarian practices are not sufficient in themselves in governing urban transformation, but they are complemented with tools of depoliticisation. For instance, law violations take place to exclude debate within democratic institutions, while participatory mechanisms exist, but are undermined to avoid public participation. In the meantime, an enforced consensus is being portrayed through controlled media, which takes depoliticisation a step further and reduces the urban public debate to the economic and aesthetic dimensions.

One of the very important forms of depoliticisation is the post-political condition. According to MoufFe (2005), the political is defined by the antagonistic dimension which she considers as constitutive of human society. While politics is "a set of practices and institutions through which an order is created, organizing human co-existence in the context of conflictuality provided by the political" (p. 9). The post-political emerges when the political is reduced from politics, and as a result, politics turns to be a mere set of "technical moves and neutral procedures" - in other words, when democratic institutions provide 
space for only consensual politics, rather than representing a shared symbolic space for conflict among adversaries (p. 9). SwYNGEDOUw (2007) has introduced what he calls "the post-political city". He argues that the shift of city government's role from managerial to entrepreneurial which accompanied neo-liberalisation has led to the "foreclosure of the political". This constitutes a post-political condition based on the replacement of conflict between different parties over power, leading to a collaboration between technocrats within a framework of universal consensus (pp. 4, 10).

Constructing a consensus is a crucial element for both Mouffe and SwYNGEDOUw. However, as competitive authoritarian systems would rather bypass a democratic institution rather than invest in developing consensual politics, I argue that the post-political is not a precise reflection of the form of depoliticisation which takes place within these systems. Although MoufFE's and SwYNGEDOUw's approaches to technocratic politics remain insightful to the study, it follows the definition of FAWCETT et al. (2017) of depoliticisation. This concept as well was developed to study democratic deficiencies focusing on the Global North, however, it still provides a more flexible approach to depoliticisation, which remains applicable within competitive authoritarianism. FAWCETT et al. (2017, p. 6) define depoliticisation as "a set of processes (tactics, strategies and tools) that remove or displace the potential for choice, collective agency and deliberation around a particular political issue". They, as well, look at the replacement of political decisions by technocratic and technical decisions. They argue that depoliticisation is a set of processes that are embedded in the democratic rule but is directed towards reducing the political to remove collective agency.

\section{Same same but different: identifying proximity between paradigms of developing megaprojects in the core and the periphery}

The study focuses on two contested megaprojects, the Belgrade Waterfront (BWF) and Tirana's New Theatre through which Belgrade and Tirana are pursuing urban development which aims at attracting investment, fostering economic growth and enhancing city competitiveness. Belgrade and Tirana are the capital cities of Serbia and Albania, which are located in South-Eastern Europe. As they have both witnessed war/civil war until the late 1990s, their transformation processes have been delayed, unlike other cities within the region. Importantly, Serbia and Albania applied for European Union Membership in the late 2000s. The delayed start created an urge out of catching up. Hence, urban transformation of the capital cities became central component of Albanian and Serbian post-socialist transitions.

Megaprojects are considered as an absolute necessity and trump cards for the two cities. The BWF and the Theatre are not the only or first megaprojects for either of the two cities: a large number of projects have been planned and announced over the last two decades. In Belgrade, various megaprojects have been announced and even defined as "topics of priority", such as Beko Master Plan, City on Water, Ada Bridge and Beton Hall. Except for the Ada Bridge and the BWF, none of the projects were realised for different reasons, as discussed by Vukmirović (2015) and Lazarević (2015). Similarly, in Tirana, the The- 
atre is only a part of a much broader transformation of the city centre which includes the extension of the central boulevard, the Tower, 4 Ever Green and the Eye of Tirana mixeduse towers and the renewal of Skanderbeg Square.

What makes the BWF and the Theatre central for this study is that they are being realised. They are also the grandest projects in the two cities, representing the physical manifestation of Belgrade's and Tirana's aspirations to reposition themselves within the global hierarchy of cities by copying the attributes and paths followed by global cities. Consequently, they are not just viewed as an absolute necessity but also as an incontestable and inevitable development of Belgrade and Tirana. This pressing and incontestable necessity has been employed in both cities to legitimise undemocratic practices and discourses. The two projects have been publicly contested, as the movement "Don't Let Belgrade Drown" (NDB) and the "Alliance for the Protection of the Theatre" have formulated mechanisms to challenge and contest the enforced depoliticised nature of urban transformation. The emergence of the two movements created forces of politicisation of urban development facing the forces of depoliticiation in Tirana and Belgrade.

This section first presents the proximity between the paradigms of developing megaprojects in global cities which Belgrade and Tirana aspire to emulate, along with the paradigms actually followed by the two cities. Then, it provides a brief overview of the two projects.

Cities of the Global North represent an important core which South-East European cities aspire to catch up with. Studies analysing the features of megaprojects in some of these core cities show that, (1) complexity and uncertainty are argued to be integral components of decision-making processes for such large scale projects (SALET et al. 2013); (2) this complexity legitimises depoliticisation (VENTO 2017); (3) they are risky and speculative (FAINSTEIN 2008); (4) they aim at ambitious goals such as positioning the city within the global competition of places (BorNSTEIN 2010); (5) SWYNGEDOUW et al. (2002, pp. 195-225) also highlight that (6) they are a "material expression" of "development rationale" which predominantly seek "generating future growth and waging a competitive struggle to attract investment capital"; (7) they reflect a "primacy of project-based initiatives over regulatory plans and procedures"; (8) they are representative of the shift from a social to a spatial definition of development, in which places rather than people are targeted; (9) often they are not well integrated into planning systems and are detached from the urban fabric; (10) they bypass local governance, with the national government and investors being the leading actors.

Beyond the Global North, cities such as Singapore and Dubai have managed to position themselves as global cities, and they have widespread influence. Dubai over the last decades succeeded in providing a global model in real estate (ELSHESHTAWY 2009). The Dubai model is based on transnational investor urbanism which is specialised in producing spectacles of mixed-use mega developments dedicated to the well-off (KoELEMAIJ 2020). Most of these features were identified in the BWF project (KoELEMAIJ 2020), which is, as explained below, built by an Emirati developer.

Megaprojects in Tirana and Belgrade have not recorded any significant differences from the previously discussed paradigms. Studies on megaprojects in the two cities (1) emphasise that such projects aim at symbolising the city's European identity and express the neo-liberal trend in urban planning; (2) elaborate that mega projects rely on transna- 
tional flows of capital; (3) highlight the major role of investors and international architects and the exclusion of the citizens; (4) argue that promised economic growth and prosperity are the main drivers of the megaprojects and (5) point out to the efforts of directing public debate towards aesthetic aspects of the projects and away from their problematic nature (Vukmirović 2015; LaZarević 2015; Pojani 2015; 2018; Koelemaij 2020).

Such proximity between the paradigms of megaprojects demonstrates that cities of the Global North and cities in South-East Europe are not in two separate universes. As well, it exemplifies the processes of copying the attributes of the centre to catch up with it, through transferring the built environment, economic and financial model as well as governance strategies.

\section{Belgrade Waterfront}

The BWF is a US dollars 3-billion brownfield urban renewal development. It is located in the centre of Belgrade, along the east bank of River Sava. The mega development occupies slightly over 2 million $\mathrm{m}^{2}$. It is a joint venture between the Republic of Serbia and $E a$ gle Hills, an Abu Dhabi-based private real estate investment and development company. According to the joint venture, the profit share of the investor is more than double of the state's profit. More importantly, Mohamed Alabbar is the representor of the investor and at the meantime the guarantor. ${ }^{4)}$ Simply, Alabbar guarantees himself. ${ }^{5)}$

The project was first announced in the 2012 local elections and then later presented in the 2014 parliamentary elections as part of the campaigns of the Serbia Progressive Party (SNS). The project was glorified by underlining its role in fostering the economy, attracting tourists and solving various socioeconomic problems, including unemployment (CukIC et al. 2015). The idea of developing the waterfront was however not born in 2012. It has already appeared in the 1972 General Plan, and kept reappearing afterwards, until it was lately realised (KADIJEVIC and KovaCEVIC 2016).

BWF, as many other megaprojects around the world, is a spectacular architecture and mixed-use development. It encompasses the largest shopping mall in the Balkans, Serbia's tallest tower, Kula Belgrade, which is designed by Chicago based Skidmore, Owings \& Merrill Global Architects (SOM), high-rise buildings, hotels, residential units, offices, etc. The project is currently under construction with some units being already occupied. In 2015, the project forcibly evicted residents from their homes in the Savamala neighbourhood. The project also displaced transport infrastructure, such as the main bus station and the railway, which now passes under the city. Moreover, according to the joint venture agreement, a number of monumental buildings became part of BWF, such as Geozavod, which was renovated and turned into the BWF gallery and sales office, the post office and the historical railway station which was built in 1884 and will be turned into a museum. The Bristol hotel - one of the oldest hotels in Belgrade - currently hosts

\footnotetext{
4) The Joint Venture Agreement: The Belgrade Waterfront Project, is available on: https://www.slideshare.net/ slobodandjukic988/jv-agreement-belgrade-waterfront-project-ugovor-o-zajednickom-ulaganju-u-projekatbeograd-na-vodi.

5) Alabbar is also the chairman of Emaar, which developed the highest tower and the biggest mall in the world in Dubai.
} 
displaced Yugoslav army families who were "temporarily" settled there in early 1990s and is now included in the project. Its residents are now facing the threat of eviction (NiKOLIC 2018).

\section{Tirana New National Theatre}

In March 2018, the Albanian Prime Minister Edi Rama announced a new modern theatre by a top architect to replace the current National Theatre. Shortly after, the Copenhagen-based Bjarke Ingels Group (BIG) was named. According to BIG, the theatre will be built over $9300 \mathrm{~m}^{2}$ in the centre of Tirana, and it is commissioned by a local developer $\mathrm{Fu}$ sha Sh.p.k. The historical theatre was demolished, during summer 2020, after a long and dedicated resistance by the Alliance. The project will be implemented as a private-public partnership (PPP). According to the government, public resources are insufficient to renovate the building. Importantly, Fusha is believed to have strong connections to the Socialist Party (SP), ${ }^{6}$ and he was described as the "almost exclusive contractor of the Tirana municipality" (Exit 2018).

The New Theatre is planned to replace the National Theatre, which was built in 1939 by the Italian authorities. "It was a cultural and recreation centre" (MENGHINI et al. 2012, p. 201). The building is considered as cultural heritage and it used to be on the list of protected monuments, until it was removed to enable its demolition (MALI 2018).

Although BIG on its website only mentions the theatre-building, the project which was proposed by the developer and voted for by parliament states that the new theatre-building makes up only 40 percent of the development, while the remaining 60 percent is dedicated to commercial towers (Tirana Echo 2018; ÇELA and ErEBARA 2018). Bjarke Ingels, architect and founder of BIG, has briefly mentioned in an interview with Top Channel Albania (cf. INGELS 2018) that the project includes these towers, however without giving any further details. Among many other indicators, this shows the lack of transparency among all the involved actors.

\section{Entangled and intricately connected processes of depoliticisation and peripheralisation}

This section foregrounds the relation between depoliticisation and peripheralisation through analysing urban governance discourses and practices around the BWF and the Theatre in Tirana. Importantly, depoliticising discourses and practices are analysed as processes, composed of strategies, tactics and tools, following the definition of FAWCETT et al. (2017). The study focuses on two strategies of depoliticisation; instituting exclusive decision-making processes under a cover of democratic rules and procedures and reducing the political within public debate. As the analysis demonstrates, depoliticisation and peripheralisation are not merely two phenomena which are logically connected on an abstract level, but rather are intricately connected and entangled. While peripherality and global

6) The current Prime Minister and the Mayor of Tirana belong to the SP. 
city aspirations legitimise depoliticising urban transformation, depoliticisation discourses and practices, in turn, construct further peripheralisation.

Importantly, depoliticisation here is not studied as a set of scattered actions, but rather strategies, which are not necessarily planned in advance but can evolve spontaneously based on the political context in a specific moment. Although the way depoliticisation is practiced makes it seem more like scattered actions, the analysis shows that such actions have an inherent logic which brings them together. Consequently, analysing them as strategies rather than individual actions reveals patterns and deepens our understanding of depoliticisation. Hence, the section addresses three questions, (1) what is depoliticisation in this context and how is it practiced? (2) how does peripheralisation contribute to legitimising depoliticising urban transformation in Belgrade and Tirana? and (3) how does depoliticisation construct further peripheralisation?

\section{Depoliticisation strategies}

The analysis brings together a set of processes which remove collective agency and the potential of choice around the BWF and the Theatre. The first strategy aims at ensuring the exclusivity of decision-making processes. It is based on practices which not only reduce engagement of citizens, but also limit the involvement of certain public democratic institutions and political actors. The second strategy focusses on systematically depoliticising the discourse related to the two projects, by glorifying and underlining the complex and technocratic nature of the projects.

\begin{tabular}{|c|l|l|}
\hline STRATEGIES & \multicolumn{1}{|c|}{ TACTICS } & \multicolumn{1}{c|}{ TOOLS } \\
\hline \multirow{2}{*}{$\begin{array}{c}\text { Strategy I: } \\
\text { Exclusive Decision } \\
\text { Making }\end{array}$} & $\begin{array}{l}\text { Disabling official participation } \\
\text { mechanisms }\end{array}$ & Façade \\
\cline { 2 - 3 } & $\begin{array}{l}\text { Enforcing state of } \\
\text { exceptionalism }\end{array}$ & Not public \\
\cline { 2 - 3 } $\begin{array}{c}\text { Strategy II: } \\
\text { Dominant Depoliticised } \\
\text { Discourse }\end{array}$ & Glogislative modifications \\
\cline { 2 - 3 } $\begin{array}{c}\text { Gifying the projects } \\
\text { Weakness }\end{array}$ & $\begin{array}{l}\text { Utilisation of institutional } \\
\text { aesthetic and economic aspects }\end{array}$ \\
\hline
\end{tabular}

Source: Author's own design

Table 1: Strategies of depoliticisation

The establishment of an exclusive decision-making process behind a democratic façade was realised in the two cases in different forms. Although Albanian and Serbian laws state that public participation is obligatory within urban governance processes, this has not always been the case in practice. According to Dr. Ledian BREGASI, head of the Albanian Union of Architects and Urban Planners (AUA), public participation takes place in some 
of the local small-scale interventions, however, it is "almost inexistent when it comes to megaprojects" (Interview by author June 2019). A. L., architect and member in the NDB, echoed Dr. BREGASI's position, saying: "In Serbia, the reason behind not having real public participation, is not the law but rather the application of the law and the political will" (Interview by author Dec. 2018).

Although disabling public participatory mechanisms was followed in both projects, the tools used varied. In Tirana, the meetings could not be considered public hearings, even though they were based on an invitation by the Mayor. In an attempt to reduce the demolition from public to a specific group issue, all theatre related meetings took place in fancy hotels and only artists were invited. A. T., an actress and active member of the Alliance, stated: "There was no choice, the decision was already taken, these meetings were just part of the show." A. K., member of the Alliance and a political analyst, said that as an uninvited Albanian citizen, she tried to attend one of those meetings and was refused entry by the Mayor's staff. She was told: "You cannot go to somebody's home without invitation" (Interview by author Jan. 2019). In Belgrade, on the contrary, public hearings took place in the city council and they were more inclusive in terms of the attendees. However, comments were often dismissed. H. S., a member of the NDB, said: "We took the public hearing very seriously, and tried to present a counter argument, however, we were simply not heard" (Interview by author Dec 2018). The BWF public hearings symbolise MoufFE's (2005) post-political democracy, where democratic institutions do not provide a shared symbolic space for conflict among adversaries, as only consensus is allowed and there is no space for disagreement.

The second tactic expands exclusion beyond citizens, to certain public institutions, and political actors. This was implemented by enforcing a state of exceptionalism concerning all related legislative issues, as well as utilising the weakness of some democratic institutions. Issuing special laws to bypass the current rules was one of the first actions in the two cases. Moreover, the decision-making process has been completely dominated by national state institutions, while local authorities were almost entirely excluded. This is a full realisation of the state of exceptionalism and centralisation which frame megaprojects in the Global North, as discussed earlier. Importantly, exceptionalism and centralisation were accompanied by some of the features of competitive authoritarianism, as the interventions by Rama, Prime Minister of Albania, and Vučić, the Serbian President, show.

After publicly announcing the New Theatre in March 2018, Rama declared that the project would not follow regular legislative and institutional procedures, but would be regulated by a special law, which was passed by the national parliament later in the same year. ${ }^{7)}$ The Special Law granted the socialist majority national parliament the authority to expropriate the land, although it was under the jurisdiction of the municipality. Bypassing the municipal council, at that time was a necessity as the SP could not attain a majority vote (van Gerven Oei 2018a; Rehova 2018). Moreover, the Special Law entailed a second legal violation, as it has explicitly referred to the developer Fusha, which was selected without any public tender. Later, President Meta returned back the law to the parliament arguing

7) The Special Law is available in Albanian on: http://konsultimipublik.gov.al/Konsultime/Detaje/62. 
that it contradicts the constitution. ${ }^{8)}$ The European Commission, as well, criticised it due to the lack of public tender (VAN GERVEN OEI 2018b). In the updated version of the law, Fusha was not mentioned and a public tender took place, in which Fusha, unsurprisingly, won.

In the case of BWF, state of exceptionalism was enforced from the very beginning. The project was initiated in an Agreement of Cooperation between the Republic of Serbia and United Arab Emirates in February 2013. As international agreements supersede domestic laws once ratified, the new agreement bypasses a broad range of laws, including PPP and concessions laws. Moreover, the BWF was declared as a "Specially Designated Area" and the project was considered of national importance in May 2014. These two steps legitimised a series of exceptional frames that were created over the following year (LALOVIC et al. 2015).

According to the Belgrade Master Plan 2021 conducting international competitions was obligatory for urban planning. This hurdle was overcome by modifying the Master Plan in September 2014 (GrubBAUER and ČAMPRAG 2018). The state of exceptionalism expanded to redefining public interest to allow land expropriation in BWF. According to Serbian law, the state can expropriate land only in the case of developing public facilities. As BWF is a commercial and residential project, the law could not be applied. For that reason, in April 2015, one more obstacle was removed by issuing a Lex Specialis (Special Law) that confirmed the status of public interest to this specific private project and organised expropriation procedures (GRUBBAUER and ČAMPRAG 2018).

Depoliticising public discourse went hand in hand with establishing an exclusive decision-making process. Glorifying the project is one of the main tactics. Both Albanian and Serbian governments have emphasised the transformative capacity of the project for the whole city and promised unprecedent economic prosperity while the developers and top architects have contributed through visualising the glory. About the BWF, Vučić stated in a press conference, that the BWF project "will make Belgrade a regional centre and it will attract many tourists" (as qouted by SEKULARAC 2014) echoing Rama and the Mayor of Tirana Erion Veliaj and their presentation of the New Theatre's role in transforming the city to a creative centre. Veliaj, in an official speech, referred to the project as "BIG's new project" stating that it will put the city on the "fifth gear" (as quoted by MYALL 2018). This reduction of urban development to its expected economic benefits and aesthetics views the issue as black and white, and provides it with a consensual frame, as SwYNGEDOUw would refer to it. Any opposition to the project is presented as against the greater good, urban development and economic growth. It then aims at leaving no space for debating the core essence of the project and its impacts.

Lastly, urban planning and development related issues have been considered by officials in the two cities as complex and technocratic. Folic, Belgrade's City Architect, described public reaction to turning some spaces in the centre to pedestrian areas, saying: "People are simply not ..., you know, he is a doctor, he does not need to be an urban planner, he can't understand the end result until he sees it' (Interview by author Dec. 2018).

\footnotetext{
8) While President Ilir Meta is expected to be politically neutral, he is often seen as politically aligned with the Democratic Party. Additionally, the president according to the constitution can only return a law twice, after that the parliament can issue the law, if the Constitutional Court has not considered it as unconstitutional. This is currently not possible as the Constitutional Court is paralysed as a consequence of on-going judicial reforms.
} 
Folic believes that citizens lack the necessary technical knowledge, consequently, they are denied any form of agency over how their city should look like. Rama has also viewed the whole project as a technical problem which needs technical solution by posting experts' opinions to social media to assert that the National Theatre building is technically unfixable (ABC News Albania 2019). On the other hand, he denied citizens the right to oppose the project by saying: "Who doesn't agree has all the respect but doesn't have mandate and rights to prevent it" (Shqiptarja.com 2019).

\section{Constructing the periphery and legitimising depoliticisation}

My study, as discussed earlier, approaches the periphery as a construct rather than a static position. Hence, this section explores how depoliticisation contributes to constructing peripherality through discourse and decision-making processes. Discourse is an important analytical element for both concepts of depoliticisation (SWYNGEDOUW 2007) and peripheralisation (PAASI 1995; CARTER 2015). Drawing on PAASI's and CARTER's analysis of the discursive construction of peripheralisation, the study shows that the very same discourse which aimed at glorifying the projects, reaffirms the peripheral position of the city and the need to achieve the project to become closer to the core.

This has been expressed in the discourse of state officials as well as the projects' branding documents. While Vučić promised that the BWF will make "Belgrade regional centre", Veliaj highlighted the transformative capacities of the New National Theatre, saying that it will be the "crown jewel" of the "unprecedent transformation" the city is going through. Rama has also stated that the new theatre will make the city a "cultural destination of European proportions" (as quoted by BLOCK 2020). Branding documents of the BWF also underlines enhancing the position of the city, by making it an "international destination", "a new centre of gravity" and "one of the most vibrant capitals in the world". Moreover, economic benefits and potentials were very central in the public discourse, including the promise of attracting tourists, investments, entrepreneurs, etc. Even more so, the developer, Eagle Hills, in its corporate mission promises "providing sustainable economic growth" to "emerging countries". The utilisation of economic potential reaffirms that Tirana and Belgrade are currently economically peripheral, and that their only way to be central is to realise these specific megaprojects. Although the projects are aimed at making their host cities more central, the discourse used is counterproductive, as it instead portrayed the cities' peripherality.

The construction of peripherality goes beyond the discourse on governance strategies and decision-making processes. One of the main features of peripheralisation, according to PoSCoPP (2015), is copying the attributes of the centre. In the case of planning and governing the BWF and the new theatre various elements were replicated to attain the global city aspirations, including copying the built environment of CBDs of global cities. But importantly, this extends to their governance strategies. As argued before, depoliticisation could be explained by the competitive authoritarian nature of the political systems in Serbia and Albania. However, the analysis has shown that this is not a sufficient explanation. Authoritarian practices, such as violently repressing critical voices, were systematically complemented by depoliticisation strategies to provide the legal and consensual cover for 
coercion. Importantly, all the depoliticisation strategies followed in the two cases inherit elements of strategies practiced in megaproject governance in global cities, which are discussed in the previous section.

Peripherality and the aspirations to catch up with global cities serve as a legitimisation not just of the projects themselves but also their governing strategies. Disabling participation channels and enforcing a state of exceptionalism were compromised to achieve the world city aspirations. Portraying the projects as the sole prestigious trump card to achieve economic growth and enhance the city's competitiveness left no space to look at core issues, such as the financial burden on the city, who bears the cost and who enjoys the benefits. Questioning the essence of the project is considered as crippling and muddling the perfectly smooth pre-determined paths of the projects and has been systematically deterred. This is exemplified in violently repressing critical voices, as a huge number of the activists in both cities have witnessed either physical violence, lost their jobs or faced defamation. The public participation mechanisms became part of the show, as one of the activists put it.

Local authorities were completely excluded, and the decision-making process became very centralised. Concretely, the national government and the developer monopolised the decision-making process and entirely excluded citizens and local authorities. Special laws were passed, and exceptional measures were taken to provide the project with a frame of legality. Even the definition of public interest by the law was amended to make one specific project possible. The underlying logic of the projects is, that they give cities a rare chance to finally leave the periphery behind, achieve economic growth, attract investments and tourists, generate jobs and economic opportunities and most importantly be able to compete with other global cities. Capitalising on this rationale, the projects become incontestable, and questioning any aspect of the project is framed as undermining the progress of the city and the country as a whole.

\section{Conclusion}

The study foregrounds the complex relation between peripheralisation and depoliticisation as an adopted governance strategy of urban transformation. It has empirically explored this relation through analysing governance discourses and practices of two megaprojects, the Belgrade Waterfront (BWF) and Tirana's new theatre. The analysis addresses three main questions; the first is on the nature of depoliticisation and how it is practiced, while the second and the third questions tackle the entangled relation between depoliticisation and peripheralisation. The article demonstrates that while the latter serves as legitimisation of the former, the former contributes to constructing the latter. Analysing the discourses around the two projects shows how city and state officials as well as the projects' developers have systematically depoliticised not only the projects but also urban development in general. In the meantime, the discourses which aimed at glorifying the projects and their capacity to reposition the city from the periphery to the core, has proven to be counterproductive. They have instead reinforced the peripherality of the city. On the other hand, adhering to the global city aspirations has contributed to legitimising not only the projects, 
but more importantly their urban governance strategies. The projects are presented as an absolute necessity and the cities' only chance to foster economic growth, and even more importantly, to enhance their competitiveness, put an end to their peripherality and bring them closer to the centre.

Conceptually, the study brings the academic debates on the concepts of peripheralisation and depoliticisation together. It foregrounds the linkages between the two concepts, which have so far not received substantial attention. Employing depoliticisation and peripheralisation as lenses to study governance of urban transformation in Belgrade and Tirana has proven to be useful, as they provide spatial analysis of political dynamics. More importantly, in combination these frames consider internal factors, such as governance strategies and the role of different national and local political actors. Simultaneously, they factor in regional and international trends and dimensions, such as the world economy, financialised globalisation and geographies of centrality. In further research it would be interesting to inquire if this connection of peripheralisation and depoliticisation is primarily a phenomenon of the European periphery or if this can equally be observed in aspiring cities globally, such as in Sub-Saharan Africa and South Asia.

Global city aspirations have proven to be a mirage which Belgrade and Tirana are continuously trying to attain. However, on the way to catch the mirage, democratic practices and principles, the right to the city and rule of law are being sacrificed. Moreover, the inability to practice citizenship and the feelings of exclusion and alienation were expressed very loudly during the interviews conducted with active citizens and members of the NDB and the Alliance. Although, the negative effects of depoliticising urban transformation and urban governance are endless, in my view, their only positive effect is the emergence of such movements as forces of politicising the urban realm. Depoliticising urban transformation and directing city developments towards achieving their global city aspirations do not only cause the exclusion of citizens from decision-making, but also, they mean excluding most of the city dwellers from the services offered by the new developments as they are not affordable. Lastly, the model produced by such dynamics cannot be sustainable. For that reason, local and international agencies working on urban development need to pay attention to major damaging effects such as weakening democratic institutions especially but not exclusively of local authorities as well as eliminating public participation, community engagement and an adequate environment for a free civil society.

\section{References}

ABC News Albania (2019): Rama sjell opinionin e Papagjonit për Teatrin [Rama brings Papagoni's opinion on the Theatre]. Tirana: ABC. - http://abcnews.al/rama-sjell-opinionin-e-papagjonit -per-teatrin/ (accessed on August 12, 2019).

Albanian Daily News (2016): Civil Society Organizations, Strong Objection to Tirana's Regulation Plan. Tirana: Albanian Daily News. - https://www.albaniandailynews.com/index.php? mod $=$ $2 \& i d m=10415$ (accessed on July 30, 2019).

Aly H. (2019): Royal Dream: City Branding and Saudi Arabia's NEOM. In: Middle East - Topics \& Arguments, 12, pp. 99-109. 
Bassens D., van Meeteren M. (2015): World Cities under Conditions of Financialized Globalization: Towards an Augmented World City Hypothesis. In: Progress in Human Geography, 39 (6), pp. 752-775.

BeIER R. (2019): Worlding Cities in the Middle East and North Africa - Arguments for a Conceptual Turn. In: Middle East - Topics \& Arguments, 12, pp. 28-34.

Bieber F. (2018): Patterns of Competitive Authoritarianism in the Western Balkans. In: East European Politics, 34 (3), pp. 337-354.

Buelotomic S. (2019): Belgrade Mayor Refuses to Disclose Contract on Belgrade Waterfront. Serbian Monitor. Belgrade: Serbian Monitor.com. - https://www.serbianmonitor.com/en/ ombudsman-mayor-refuses-to-disclose-contract-on-belgrade-waterfront/ (accessed on August 12, 2019).

Block I. (2020): Protests in Tirana as Albanian National Theatre Demolished to Make Way for BIG Project. In: dezeen Magazine. - https://www.dezeen.com/2020/05/19/protests-tiranaahead-big-albanian-national-theatre-demolished-news/ (accessed on August 15, 2020).

Bodenheimer S. (1970): Dependency and Imperialism: The Roots of Latin American Underdevelopment. In: NACLA Newsletter, 4 (3), pp. 18-27.

BornsteIn L. (2010): Mega-Projects, City-Building and Community Benefits. In: City, Culture and Society, 1 (4), pp. 199-206.

Caporaso J. A. (1978): Dependence, Dependency, and Power in the Global System: A Structural and Behavioral Analysis. In: International Organization, 32 (1), pp. 13-43.

Carter H. (2015): Peripheralization through Planning: The Case of a Golf Resort Proposal in Northern Ireland. In: Lang T., Henn S., Sgibnev W., Ehrlich K. (eds.): Understanding Geographies of Polarization and Peripheralization: Perspectives from Central and Eastern Europe and Beyond. London: Palgrave Macmillan, UK, pp. 98-114.

Çela L., Erebara G. (2018): Zbulohet projekti i "Fushës" me afro 90 mijë metra katrorë kulla dhe Teatër[Fusha's Project of nearly 90,000 m2 of Tower and Theater is Unveiled]. Tirana: Reporter.al. - https://www.reporter:al/zbulohet-projekti-i-fushes-me-afro-90-mije-metra-katrorekulla-dhe-teater/ (accessed on August 4, 2019).

Cukic I., Sekulic D., Slavkovic L., Vilenica A. (2015): Report from Belgrade Waterfront. Vienna: Eurozine. - https://www.eurozine.com/report-from-belgrade-waterfront/ (accessed on August 4, 2019).

Elsenhans H. (2015): The Concept of the Periphery as a Constitutive Part of the Capitalist World System. In: Middle East - Topics \& Arguments, 5, pp. 14-23.

ElsheshtaWy Y. (2009): Redrawing Boundaries: Dubai, an Emerging World City. In: Elsheshtawy Y. (ed.): Planning Middle Eastern Cities: An Urban Kaleidoscope in a Globalizing World. London: Routledge, pp. 169-199.

Exit (2018): Fusha Shpk Receives over $€ 43$ Million from Municipal Contracts. Tirana: Exit.al Explaining Albania. - https://exit.al/en/2018/08/04/fusha-shpk-receives-over-e43-millionfrom-municipality-contracts/ (accessed on August 4, 2019)

FAINSTEIN S. (2008): Mega-Projects in New York, London and Amsterdam. In: International Journal of Urban and Regional Research, 32 (4), pp. 768-785.

Fawcett P., Flinders M. V., Hay C., Wood M. (2017): Introduction: Anti-Politics, Depoliticization, and Governance. In: Fawcett P., Flinders M. V., Hay C., and Wood M. (eds.): Anti-Politics, Depoliticization, and Governance. Oxford, UK: Oxford University Press, pp. $3-27$.

Fischer-TAhiR A., NAumann M. (2013): Introduction: Peripheralization as the Social Production of Spatial Dependencies and Injustice. In: Fischer-Tahir A., NAumann M. (eds.): Peripheralization. Wiesbaden: Springer, pp. 9-27. 
Friedmann J. (1986): The World City Hypothesis. In: Development and Change, 17 (1), pp. 69-83. Goldfrank W. L. (2000): Paradigm Regained? The Rules of Wallerstein's World-System Method. In: Journal of World-Systems Research, 6 (2), pp. 150-195.

GrubBauer M., ČAmPRAG N. (2018): Urban Megaprojects, Nation-State Politics and Regulatory Capitalism in Central and Eastern Europe: The Belgrade Waterfront Project. In: Urban Studies, 56 (4), pp. 649-671.

HaLl, P. (1966): The World Cities. London: Weidenfeld and Nicolson.

HaRvey D. (1989): From Managerialism to Entrepreneurialism: The Transformation in Urban Governance in Late Capitalism. In: Geografiska Annaler. Series B, Human Geography, 71 (1), pp. 3-17.

Harvey D. (2001): Globalisation and the "Spatial Fix". In: Geographische Revue, 3 (2), pp. 23-30.

Ingels B. (2018): Talk Show with Bjarke Ingels 14 March 2018. In: Top Channel Albania, Top Show Magazine, Talk ShowYoutube. Tirana: Top Channel Albania. - https://www.youtube. com/watch? $v=$ UnKLaLv5Z40\&feature $=$ youtu.be. $/($ accessed on September 20, 2018).

KadiJevic A. Đ., Kovacevic B. S. (2016): Degradative Urbanistic and Architectural Aspects of the Project "Belgrade Waterfront" (2012-2016). In: Matica Srpska Journal for Fine Arts Novi Sad, 44, pp. 367-377.

KoelemaiJ J. (2020): Dubaification in Practice: An Inter-Scalar Analysis of Belgrade Waterfront. In: Urban Geography, online only, 19 pp. - https://doi.org/10.1080/02723638.2020.1721205.

Lalovic K., Radosavljevic U., Duukanovic Z. (2015): Reframing Public Interest in the Implementation of Large Urban Projects in Serbia: The Case of Belgrade Waterfront Project. In: Facta Universitatis - Series: Architecture and Civil Engineering, 13 (1), pp. 35-46.

LAZAREvić E. V. (2015): Urban Regeneration Tools (City Branding) in Belgrade after the Democratic Change in 2000 - Social Frame. In: Doytchinov G., Đukić, A., Ionita, C. (eds.): Planning Capital Cities: Belgrade, Bucharest, Sofia. Graz: Verlag der Technischen Universität Graz [Technical University of Graz Press], pp. 174-187.

Mali T. (2018): Albania: The Theatre of Politics. In: Osservatorio Balcani e Caucaso Transeuropa. Trento: OBC Transeuropa. - https://www.balcanicaucaso.org/eng/Areas/Albania/Albaniathe-theatre-of-politics-186950 (accessed on April 10, 2018).

Menghini A. B., Pashako F., Stigliano M. (2012): Architettura Moderna Italiana per Le Città d Albania: Modelli e Interpretazioni (Modern Italian Architecture of the City of Albania: Model and Interpretation). Bari: Politecnico di Bari (= Archinauti | Monografie, 36).

Moufre C. (2005): On the Political. Thinking in Action. London: Routledge.

Myall N. (2018): BIG Takes Centre Stage in Albania. In: World Architecture News. Twickenham, UK: Haymarket Media Group. - https://www.worldarchitecturenews.com/article/1518384? utm_source $=$ website\&utm_medium $=$ social $($ accessed on August 12, 2019).

Namkoong Y. (1999): Dependency Theory: Concepts, Classifications, and Criticisms. In: International Area Review, 2 (1), pp. 121-150.

NikoLIC I. (2018): Belgrade's Neglected Landmark Hotel Awaits Its Rebirth. In: BalkanInsight, Belgrade 18/12/2018. - https://balkaninsight.com/2018/12/18/belgrade-s-neglected-landmarkhotel-awaits-its-rebirth-12-10-2018/(accessed on August 12, 2019).

ONG A. (2011): Introduction: Worlding Cities, or the Art of Being Global. In: Roy A., ONG A. (eds.): Worlding Cities: Asian Experiments and the Art of Being Global. Oxford, UK: Wiley-Blackwell, pp. 1-26.

PAasi A. (1995): The Social Construction of Peripherality: The Case of Finland and the Finnish-Russian Border Area. In: Eskelinen H., Snickars F. (eds.): Competitive European Peripheries, Advances in Spatial Science. Berlin / Heidelberg: Springer, pp. 235-258.

Pojani D. (2015): Urban Design, Ideology, and Power: Use of the Central Square in Tirana during One Century of Political Transformations. In: Planning Perspectives, 30 (1), pp. 67-94. 
Pojani D. (2018): Cities as Story: Redevelopment Projects in Authoritarian and Hybrid Regimes. In: Journal of Urban Affairs, 40 (5), pp. 705-720.

PoSCoPP - Research Group Production of Space in the Context of Polarization and Peripheralization (2015): Understanding New Geographies of Central and Eastern Europe. In: LANG T., Henn S., Sgibnev W., Ehrlich K. (eds.): Understanding Geographies of Polarization and Peripheralization: Perspectives from Central and Eastern Europe and Beyond. London: Palgrave Macmillan, pp. 1-21.

Rehova I. (2018): The National Theater Project Is Legally Sanctioned Theft. Tirana: Exit.al Explaining Albania. - https://exit.al/en/2018/07/04/the-national-theater-project-is-legallysanctioned-theft/ (accessed on April 10, 2019).

Roy A., ONG A. (2011): Worlding Cities: Asian Experiments and the Art of Being Global. Oxford, UK: Wiley-Blackwell.

Salet W., Bertolini L., Giezen M. (2013): Complexity and Uncertainty: Problem or Asset in Decision Making of Mega Infrastructure Projects? In: International Journal of Urban and Regional Research, 37 (6), pp. 1984-2000.

SASSEN S. (2002): Locating Cities on Global Circuits. In: Environment and Urbanization, 14 (1), pp. 13-30.

SASSEN S. (2005): The Global City: Introducing a Concept. In: The Brown Journal of World Affairs, 11 (2), pp. 27-34.

Sekularac I. (2014): Serbia Relies on Gulf Cash for Belgrade Waterfront Development. In: Reuters. International Edition. - https://lta.reuters.com/article/serbia-emirates-belgrade-idUSL6N OP72X 220140627 (accessed on March 13, 2019).

Shqiptarja.com [Albanian.com] (2019): Teatri Kombëtar/ Rama: Do ndërtohet si përgjegjësi e qeverisë, asnjë minorancë nuk mund ta marrë peng (National Theater / Rama: It will be built as a government responsibility, no minority can take it hostage). In: Shqiptarja.com.Tirana, July 24, 2019. - https://shqiptarja.com/lajm/protesta-per-teatrin-rama-do-ndertohet-kushnuk-eshte-dakord-eshte-i-respektuar-por-nuk-ka-mandat-ta-pengoje (accessed on August 4, 2019).

Sмiтн N. (1984): Uneven Development: Nature, Capital and the Production of Space. Oxford: Basil Blackwell.

Swyngedouw E. (2007): The Post Political City. In: BAVO, The Bureau for Architectural Theory (eds.): Urban Politics Now. Re-Imagening Democracy in the Neoliberal City. Rotterdam: NAI-Publishers, pp. 58-76.

Swyngedouw E., Moulaert F., Rodriguez A. (2002): Neoliberal Urbanization in Europe: LargeScale Urban Development Projects and the New Urban Policy. In: Brenner N., TheOdORE N. (eds.): Spaces of Neoliberalism: Urban Reconstructing in North America and Western Europe. Hoboken, NJ: John Wiley \& Sons, pp. 194-229.

TAYLOR P. J. (2001): Specification of the World City Network. In: Geographical Analysis, 33 (2), pp. 181-194.

TAYLOR P. J. (2003): World City Network: A Global Urban Analysis. London / New York: Routledge.

TAYLOR P. J. (2018): Urbanization in Global Perspective. Loughborough: Global and World Cities GaWC) Research Network (= GaWC Research Bulletin, 463). - https://www.lboro.ac.uk/ gawc/rb/rb463.html (accessed on August 01, 2020)

Tirana Echo (2018): Albania - Fierce Debates Continue over the Replacement of a Landmark National Theater Building in the Center of Tirana. In: Tirana Echo - South East Europe from Tirana, July 27, 2018. - http://www.tiranaecho.com/latest-news/breaking-albania-fiercedebates-continue-over-the-replacement-of-a-landmark-national-theater-building-in-thecenter-of-tirana/ (accessed on July 27, 2018). 
Tirana Times (2018): Albanian Artists Hold Daily Protests to Protect National Theatre from Demolition. In: Tirana Times, July 20, 2018. - http://www.tiranatimes.com/? $p=137564$ (accessed on July 27, 2018).

van Gerven Oei W. J. (2018a): A New Theatre Demands New Laws. Tirana: Exit.al - Explaining Albania. - https://exit.al/en/2018/03/13/a-new-theater-demands-new-laws/ (accessed on March 13, 2018).

van Gerven Oei W. J. (2018b): The "Updated" Special Law for the National Theater Is Still Made for Fusha. Tirana: Exit.al - Explaining Albania. - https://exit.al/en/2018/09/20/the-updatedspecial-law-for-the-national-theater-is-made-for-fusha (accessed on September 20, 2018).

van Meeteren M., Bassens D. (2016): World Cities and the Uneven Geographies of Financialization: Unveiling Stratification and Hierarchy in the World City Archipelago. In: International Journal of Urban and Regional Research, 40 (1), pp. 62-81.

Vento A. T. (2017): Mega-Project Meltdown: Post-Politics, Neoliberal Urban Regeneration and Valencia's Fiscal Crisis. In: Urban Studies, 54 (1), pp. 68-84.

Vukmirović M. (2015): Belgrade: The Quest for the Desired City Image. In: Doytchinov G., Đukić, A., Ionita, C. (eds.): Planning Capital Cities: Belgrade, Bucharest, Sofia. Graz: Verlag der Technischen Universität Graz [Technical University of Graz Press], pp. 188-211.

WallersteIn I. 1974: The Modern World-System I: Capitalist Agriculture and the Origins of the European World-Economy in the Sixteenth Century. New York: Academic Press, Inc.

Wilson J., Swyngedouw E. (2014): Seeds of Dystopia: Post-Politics and the Return of the Political. In: Wilson J., Swyngedouw E. (eds.): The Post-Political and Its Discontents: Spaces of Depoliticisation, Spectres of Radical Politics. Edinburgh: Edinburgh University Press, pp. 1-22. 